\title{
PEMANFAATAN TEPUNG PORANG (Amorphophallusoncophyllus) SEBAGAI PENSTABIL EMULSI M/A DAN BAHAN PENYALUT PADA MIKROKAPSUL MINYAK IKAN
}

\section{APPLICATION OF PORANG FLOUR AS STABILIZER IN O/W EMULSIONAND COATING MATERIAL FOR FISH OIL MICROCAPSULES}

\author{
Sri Haryani Anwar*), Berlianta Maria Br. Ginting, Yuliani Aisyah, Novi Safriani \\ Jurusan Teknologi Hasil Pertanian, Universitas Syiah Kuala \\ Jl. Tgk. Hasan Krueng Kalee No. 3, Darussalam-Banda Aceh 23111, Indonesia \\ E-mail: sri.haryani@unsyiah.ac.id
}

Makalah: Diterima 7 Oktober 2016; Diperbaiki 1 Maret 2017; Disetujui 20 Maret 2017

\begin{abstract}
This research was aimed to investigate the ability of porang (Amorphophallus oncophyllus) flour to stabilizeoil-in-water $(\mathrm{O} / \mathrm{W})$ emulsion and further more can be used as encapsulating matrix for fish oil microencapsules. The experiments were divided into three stages: A) emulsification with ultra turrax to form coarse emulsion which designed using randomized block design with two variables, namely concentration of porang flour (55\% glucomanan) i.e. $0.5 \%$ and $1 \%$, and oil concentrations i.e. $20 \%, 30 \%$ and 40\%;B) Variables that produced stable coarse emulsions were selected to be used in fine emulsion process using high pressure homogenizer; and 3) Stable and effective fine emulsions were spray dried to produce fish oil microcapsules. Porang flour used was yellow in colour with $7.75 \%$ moisture content, $8 \%$ ash, $9.72 \%$ crude fiber, $0.43 \%$ fat and $55 \%$ glucomanan. The statistical analysis showed that all variables i.e. porang flour and oil concentrations influenced the emulsifying activity values and viscosity significantly $(P \leq 0.01)$. The most stable coarse emulsion was the one that emulsified by $40 \%$ oil and 1\% porang flour with viscosity of $3647 \mathrm{cP}$ and $100 \%$ emulsifying activity, and separation of $2.70 \mathrm{ml}$ serum layer after 7 days storage. Stable fine emulsion was produced by the same variables' combination as coarse emulsion with average droplet size of $614 \mathrm{~nm}$, polydispersity index of 0.237 , emulsion zeta potential of $-25.83 \mathrm{mV}$, and separation of only $0.25 \mathrm{~mL}$ after 16 days storage. Emulsion that spray dried effectively contained $0.5 \%$ porang flour. The peroxide values of fish oil microcapsules were in the range of $16.5-32.5 \mathrm{meq} / \mathrm{kg}$ oil.
\end{abstract}

Keywords: porang flour, glucomannan, o/w emulsion, emulsion stability, stabilizer

\section{ABSTRAK}

Penelitian ini didasari atas upaya untuk menemukan biopolimer alami yang tumbuh di Indonesia yang berpotensi digunakan sebagai bahan penyalut dalam proses mikroenkapsulasi bahan pangan. Secara khusus, penelitian ini bertujuan untuk menguji kemampuan tepung porang (Amorphophallus oncophyllus) sebagai penstabil emulsi minyak dalam air (m/a) dan bahan penyalut pada mikrokapsul minyak ikan.Penelitian ini terbagi atas 3 tahap. Tahap pertama adalah pembuatan coarse emulsion (CE) menggunakan ultra turrax (UT) dengan desain penelitian menggunakan rancangan acak kelompok yang terdiri dari dua faktor. Faktor pertama adalah konsentrasi tepung porang (kadar glukomanan 55\%) yang terdiri atas dua taraf yaituT1 $=0,5 \%$ dan $\mathrm{T} 2=1 \%$. Faktor kedua adalah konsentrasi minyak terdiri atastigataraf yaitu M1 $=20 \%$, M2 $=30 \%$ dan M3 $=40 \%$. Tahap kedua adalah pembuatan fine emulsion (FE) menggunakan high pressure homogenizer (HPH) dan tahap ketiga adalah pengeringan FE menggunakan spray dryer. Tepung porang yang digunakan berwarna kuning dengan kadar air 7,75\%, kadar abu 8,00\%, kadar serat 9,72\%, kadar lemak 0,43\%, dan kadar glukomanan 55,54\%. Berdasarkan hasil penelitian, konsentrasi tepung porang, konsentrasi minyak dan interaksi antara konsentrasi tepung porang $(\mathrm{T})$ dan konsentrasi minyak $(\mathrm{M})$ berpengaruh sangat nyata $(\mathrm{P} \leq 0,01)$ terhadap nilai emulsifying activity (EA) dan viskositas emulsi. CE yang paling stabil adalah emulsi dengan konsentrasi minyak $40 \%$ dan tepung porang $1 \%$, dengan viskositas $3647 \mathrm{cP}$, nilai EA100\% dan pemisahan serum 2,70 mL setelah 7 hari peyimpanan. FE yang paling stabil diperoleh dari kombinasi perlakuan yang sama dengan ukuran partikel ratarata $614 \mathrm{~nm}$, polydispersity index (PdI) 0,237 , zeta potential $-25,83 \mathrm{mV}$, dan pemisahan serum $0,25 \mathrm{~mL}$ setelah 16 hari penyimpanan. Nilai bilangan peroksida (PV) mikrokapsul berkisar antara $16.5-32.5 \mathrm{meq} / \mathrm{kg}$ minyak.

Kata kunci: tepung porang, glukomanan, emulsi (m/a), stabilitas emulsi, penstabil

\section{PENDAHULUAN}

Salah satu biopolimer alami yang berpotensi digunakan sebagai bahan penyalut adalah porang atau iles-iles (Amorphopallus onchopillus). Tanaman ini hanya terdapat di daerah tropis dan sub- tropis. Pemanfaatan porang dalam industri pangan ataupun non pangan masih sangat kurang. Porang tidak dapat diolah langsung menjadi makanan karena kandungan kalsium oksalat yang menyebabkan rasa gatal, sehingga sering diolah terlebih dahulu menjadi tepung atau gaplek. 
Tepung porang mengandung glukomanan yang memiliki nilai ekonomis sangat tinggi dan dapat digunakan secara luas. Tepung porang yang dimurnikan menjadi glukomanan saat ini dijadikan sebagai suplemen pangan yang dikonsumsi oleh penderita diabetes, tekanan darah tinggi, dan kolesterol. Kandungan glukomanan pada umbi porang cukup tinggi. Berdasarkan hasil penelitian terbaru yang dilakukan oleh Yanuriati et al. (2017), ekstraksi glukomanan dari umbi porang segar menghasilkan yield $65,23 \%$ dengan kemurnian 90,98\%.

Glukomanan merupakan molekul polisakarida hidrokoloid yang merupakan gabungan glukosa dan manosa dengan ikatan $\beta-1,4$ glikosida. Kandungan glukomanan pada umbi porang berbedabeda tergantung pada warna umbi. Umbi porang kuning (Amorphophallus oncophyllus Pr) mengandung sekitar 55\% glukomanan (basis kering), sedangkan pada umbi porang putih (Amorphophallus variabilis $B l$ ) kandungan glukomanannya sekitar 44\% (basis kering).

Glukomanan mengandung kadar serat yang cukup tinggi dan dapat berfungsi sebagai thickening dan gelling agent yang mampu membentuk dan menstabilkan struktur gelsehingga dapat digunakan sebagai pengenyal makanan dan pengganti lemak dalam produk pangan (Jimenez-Colmenero et al., 2012). Glukomanan juga dapat digunakan sebagai bahan tambahan makanan (BTM) seperti pada mie atau pasta dikarenakan kemampuan glukomanan yang sangat besar dalam mengikat air (Mulyono et al., 2009). Kegunaan lainnya adalah sebagai drug delivery, bioadhesive properties improvement, cellular therapy, bahan untuk immobilisasi sel, bahan enkapsulasi, film dan membran, bahan coating, kosmetik, emulsifier, dan surfaktan (Zhang et al., 2005).

Beberapa hasil penelitian membuktikan peranan glukomanan yang sangat baik terhadap produk yang dihasilkan. Haryani et al. (2012) menambahkan glukomanan sebagai bahan dalam pembuatan edible film. Edible film dengan konsentrasi glukomanan sebanyak $4 \mathrm{~g}$ memiliki karakteristik yang lebih baik seperti modulus young, daya tarik, dan pemanjangan tertinggi. Harmayani et al. (2014) menyimpulkan bahwa makanan yang disuplementasi dengan porang glukomanan dapat menghambat pertumbuhan $E$. coli dan dapat digunakan sebagai pangan fungsional.Penelitian lainnya menambahkan 0,4\% glukomanan dari bobot es krim dan menghasilkan es krim yoghurt dengan karakteristik yang baik (Jannah et al., 2013).

Tepung porang yang mengandung glukomanandigunakan sebagai stabilizer dalam penelitian ini karena diduga dapat meningkatkan viskositas fase pendispersi yang berguna dalam menstabilkan sistem emulsi bersama-sama dengan tween 80.Tween-80 adalah surfaktan non ionik dengan nilai HLB (hydrophilic lipophilic balance) sebesar 15 yang sifatnya cenderung larut dalam air (hidrofilik) dan cocok dengan sistem emulsi m/a (Koneva et al., 2017).

Karakteristik penting dari glukomanan dalam menstabilkan emulsi adalah larut dalam air, dapat meningkatkan viskositas emulsi dan memiliki daya kembang lebih tinggi dari pada gum arab serta tidak berbau jika diolah dengan bahan pangan lainnya. Penelitian yang menggunakan glukomanan sebagai penstabil emulsi belum banyak ditemukan dalam literatur.

Asam lemak omega-3 merupakan asam lemak tidak jenuh ganda yang tidak dapat disintesis oleh tubuh dan hanya dapat diperoleh dari makanan. Sumber utama asam lemak omega-3 adalah seafood khususnya ikan. Karena harga ikan yang relatif mahal, maka rata-rata konsumsi ikan dan produk hasil pengolahan ikan di Indonesia masih rendah. Pengayaan langsung minyak ikan kedalam produk pangan sulit dilakukan karena minyak ikan sangat sensitif terhadap oksidasi dan bau ikan yang amis. Salah satu cara untuk mengatasi masalah ini adalah dengan mikroenkapsulasi. Tujuan mikroenkapsulasi adalah untuk memerangkap minyak ikan dalam bahan penyalut (matriks) yang berasal dari polimer alami agar minyak ikan tidak mudah teroksidasi dan bau ikan dapat disembunyikan (odour masking).

Keberhasilan proses mikroenkapsulasi ditentukan oleh jenis bahan penyalut yang digunakan dalam proses pembuatan emulsi. Emulsi yang stabil menjadi dasar bagi produksi mikrokapsul yang stabil terhadap oksidasi. Emulsi adalah dispersi suatu cairan dalam cairan lain dimana molekul-molekul kedua cairan tersebut tidak saling berbaur. Pada suatu sistem emulsi biasanya terdapat tiga bagian utama yaitu bagian fase terdispersi, fase pendispersi dan pengemulsi yang berfungsi menjaga agar butiran fase terdispersi tetap tersuspensi di dalam fase pendispersi (McClement, 2005). Contoh produk pangan yang berbasis emulsi adalah mayonnaise, berbagai jenis minuman soft drink dan yoghurt, es krim, saus, dan sebagainya.

Hingga saat ini, penelitian-penelitian untuk menemukan kombinasi bahan penyalut yang benarbenar dapat melindungi asam lemak omega-3 dari oksidasi makin intensif dilakukan. Sulitnya mencegah oksidasi asam lemak omega-3 menyebabkan ketersediaan asam lemak tersebut dalam produk pangan masih dipertanyakan.

Tujuan utama penelitian ini adalah untuk memanfaatkan tepung porang dengan kandungan glukomanan $55 \%$ sebagai bahan penstabil emulsi minyak ikan dalam air (m/a) dengan tween 80 sebagai surfaktan. Kemampuan tepung porang sebagai bahan penyalut minyak ikan selanjutnya diuji dengan mengeringkan emulsi menjadi mikrokapsul.

Kestabilan emulsi m/a diujicobakan pada tiga tingkat konsentrasi minyak yang berbeda dan emulsi yang terbentuk diukur tingkat kestabilannya. 
Proses emulsifikasi diawali dengan pembentukan coarse emulsion dengan ultra turrax dilanjutkan dengan high pressure homogenizer untuk pembentukan fine emulsion. Fine emulsion inilah yang dikeringkan dengan spray dryer menghasilkan mikrokapsul minyak ikan.

\section{BAHAN DAN METODE}

\section{Bahan dan Alat}

Bahan bakuyang digunakan dalam pembuatan emulsi adalah tepung porang yang diperoleh dari daerah KPH (Kesatuan Pemangku Hutan) Saradan, Madiun - Jawa Timur, menhaden fish oil (Sigma), minyak kelapa sawit (Bimoli), dan larutan buffer. Bahan untuk analisis kimia yaitu isooctane, asam asetat, kloroform, sodium tiosulfat, potasium iod, indikator pati, isoheksan, etanol, dietil eter, asam klorida, $\mathrm{NaOH}$, asam sulfat pekat, aquades, phenylhydrazine hydrochloride (Sigma), Na-asetat dan arang aktif. Bahan kimia yang digunakan untuk membuat larutan buffer yaitu natrium sitrat dan penetral $\mathrm{pH}(\mathrm{NaOH}$ dan $\mathrm{HCl})$.

Alat yang digunakan dalam penelitian ini adalah high pressure homogenizer (GEA Niro Soavi-Panda PLUS), ultra turax homogenizer (IKA T25 digital), spray dryer (LabPlant SD-05), scanning electron microscope (SEM-Zeiss EVO MA 10), transmission electron microscope (TEM- FEI Technai G2 Spirit 120 KV), spektrofotometer (Shimadzu UV 1700), centrifuge (Hettich Zentrifugen - EBA 20), oven pengering (EYELAWFO-450PD), rotaryevaporator (Eyela N-1000), viscometer brookfield (LvT S/N 2068848C), light microscope infinity analyze (Meiji Techo dengan jenis kamera DSLR), gelas kimia, aluminiumfoil, tabung reaksi, gelas ukur, soxhlet apparatus, kuvet, cawan porselin, gelas ukur, buretdan desikator.

\section{Rancangan Percobaan}

Penelitian ini dilakukan dengan menggunakan rancangan acak kelompok (RAK) yang terdiri dari 2 (dua) faktor. Faktor pertama adalah konsentrasi tepung porang yang terdiri atas 2 taraf yaitu $\mathrm{T} 1=0,5 \%(\mathrm{~b} / \mathrm{v})$ dan $\mathrm{T} 2=1 \%(\mathrm{~b} / \mathrm{v})($ tidak masuk dalam hitungan total emulsi). Faktor kedua adalah konsentrasi minyak terdiri atas 3 taraf yaitu $\mathrm{M} 1=20 \%(\mathrm{v} / \mathrm{v}), \mathrm{M} 2=30 \%(\mathrm{v} / \mathrm{v})$ dan $\mathrm{M} 3=40 \%$ (v/v) dari total emulsi. Setiap perlakuan diulang 3 kali kecuali untuk analisis ukuran partikel dengan particle size analizer (PSA), pengukuran polidispersitas index (PdI) dan zeta potensial hanya dilakukan pada FE dari perlakuan terbaik saja tanpa ada ulangan. Data yang diperoleh selanjutnya dianalisis secara statistik dengan ANOVA (analysis of variance). Jika hasil pengujian menunjukkan adanya pengaruh beda nyata antar perlakuan, maka akan dilanjutkan dengan uji lanjutan beda nyata terkecil (BNT) (Sugandi dan Sugiarto, 1994).

\section{Prosedur Penelitian \\ Pembuatan Larutan Buffer \\ Larutan buffer dalam pembuatan emulsi} berfungsi untuk menjaga kestabilan $\mathrm{pH}$ emulsi selama penyimpanan. $\mathrm{pH}$ berpengaruh besar pada kemampuan pengawet asam atau fenol untuk menghambat pertumbuhan bakteri dan $\mathrm{pH}$ yang baik untuk kestabilan emulsi adalah 4,5-6. Pembuatan larutan buffer pada penelitian ini mengikuti prosedur yang dilakukan oleh Charoen et al. (2011).

\section{Pembuatan Coarse Emulsion}

Emulsi yang dibuat untuk setiap satuan percobaan sebanyak $100 \mathrm{~mL}$ dengan fase terdispersi berupa minyak bimoli. Prosedur pembuatan coarse emulsion berdasarkan penelitian yang dilakukan oleh Anwar et al. (2011) dan dibagi menjadi dua bagian sebagai berikut:

1. Bagian pertama penambahan tepung porangsebanyak $0,5 \%$ dengan tiga variasi sistem emulsi berdasarkan penambahan minyak yaitu $20 \%$, 30\% dan $40 \%$. Tepung porang ditimbang $0,5 \mathrm{~g}$ dan dilarutkan dalam larutan buffer (volume larutan buffer yang digunakan tergantung pada persentase minyak yang ditambahkan). Untuk pembuatan emulsi dengan konsentrasi minyak $20 \%$, tepung porang $0,5 \mathrm{~g}$ dilarutkan dalam $80 \mathrm{~mL}$ larutan buffer agar diperoleh $100 \mathrm{~mL}$ emulsi). Campuran kemudian dihomogenisasi dengan ultra turrax dengan kecepatan $8.000 \mathrm{rpm}$ selama 1 menit. Selanjutnya ditambahkan minyak (sesuai perlakuan) dan tween 80 sebanyak $0,5 \mathrm{~g}$ dan homogenisasi dilanjutkan dengan kecepatan 14.000 rpm selama 3 menit.

2. Bagian kedua penambahan tepung porang sebanyak $1 \%$ dengan tiga variasi sistem emulsi penambahan minyak yaitu $20 \%, 30 \%$ dan $40 \%$. Tepung porang ditimbang $1 \mathrm{~g}$ dan dilarutkan dalam larutan buffer kemudian dihomogenisasi dengan ultra turrax dengan kecepatan $8.000 \mathrm{rpm}$ selama 1 menit. Selanjutnya ditambahkan minyak (sesuai perlakuan) dan tween 80 sebanyak 0,5 gdan homogenisasi dilanjutkan dengan kecepatan 14.000 rpm selama 3 menit.

\section{Pembuatan Fine Emulsion}

Pembuatan fine emulsion merupakan tahap lanjutan setelah analisis terhadap coarse emulsion selesai. Hasil penelitian menunjukkan bahwa CE dengan konsentrasi minyak $20 \%$ ternyata tidak stabil dan cepat terpisah. Oleh karena itu variabel konsentrasi minyak yang digunakan pada pembuatan FE hanya $30 \%$ dan $40 \%$.

Proses emulsifikasi diawali dengan melarutkan bahan penyalut sesuai variabel penelitian (0,5\% dan 1\%) ke dalam larutan buffer. Campuran dihomogenisasi dengan ultra turrax T25 selama 2-3 menit dengan kecepatan 8000 rpm. Setelah tepung porang larut sempurna, minyak ikan ditambahkan 
sesuai variabel utama penelitian (30\%, dan 40\%). Campuran dihomogenkan kembali selama 2-3 menit dengan kecepatan $13000 \mathrm{rpm}$ sehingga dihasilkan emulsi dengan droplet yang lebih kecil.Selanjutnya coarse emulsion yang dihasilkan dihomogenisasi lanjut dengan high pressure homogenizer (GEA Niro Soavi, Panda Plus) menggunakan tekanan 300 bar, 2 siklus. Setelah melewati homogenisasi tahap kedua, emulsi yang dihasilkan selanjutnya dianalisis untuk melihat tingkat kestabilannya sebelum dikeringkan menjadi mikrokapsul minyak ikan menggunakan spray dryer.

\section{Proses Mikroenkapsulasi dengan Metode Pengeringan Semprot}

Prinsip mikroenkapsulasi adalah produksi mikrokapsul dengan mengeringkan emulsi M/A untuk menguapkan air sehingga terbentuk partikel mikrokapsul dengan kadar air 4-6\%. Prosedur pengeringan emulsi menjadi mikrokapsul pada penelitian ini mengikuti metode Anwar et al. (2011). Emulsi dipompakan ke dalam spray dryer dengan kecepatan tetap. Suhu udara pengeringan yang digunakan adalah $180^{\circ} \mathrm{C}$ dan suhu udara pengeluaran adalah $80^{\circ} \mathrm{C} \pm 5^{\circ} \mathrm{C}$. Proses pengeringan emulsi berlangsung hanya dalam beberapa detik dan mikrokapsul yang terbentuk ditampung pada botol kaca.

\section{Analisis}

Analisis yang dilakukan terhadap tepung porang adalah uji proksimat meliputi kadar air (SNI 01-2891-1992), kadar abu (SNI 01-2891-1992), kadar lemak (SNI 01-2891-1992), kadar serat kasar(SNI 01-2891-1992) dan analisis kandungan glukomanan dengan mannosa phenllhydrazone method (Ohtsuki, 1968). Pengukuran stabilitas coarse emulsion dilakukan dengan uji stabilitas emulsi menggunakan metode sentrifugasi dan menghitung nilai emulsifying activity (EA) sesuai metode yang ditulis oleh $\mathrm{Wu}$ (2011), melihat ukuran partikel dengan light microscope dan mengukur batas-batas lapisan yang terpisah selama penyimpanan (Weiss, 2002). Adapun untuk fine emulsion dilakukan pengukuran zeta potential (Aljamali, 2015), ukuran droplet emulsi dengan particle size analyser (PSA) (Ali, 2014) dan bentuk droplet emulsi dengan transmission electron microscope (TEM) (Flores et al., 2011). Stabilitas emulsi diukur dengan menghitung nilai creaming index (CI) selama penyimpanan sesuai rumus yang ditulis oleh McClement (2005).

Khusus untuk analisis ukuran partikel menggunakan PSA, zeta potential dan TEM dari fine emusion hanya dilakukan pada hasil terbaik dan tidak dilakukan ulangan pengukuran karena keterbatasan penggunaan alat. Namun untuk uji penyimpanan fine emulsion sampel di ukur duplo dengan dua kali ulangan dan data yang diperoleh dianalisis secara statistik.
Selanjutnya, emulsi minyak ikan yang paling stabil dan memungkinkan untuk dikeringkan dengan spray dryer dipilih untuk dikeringkan sehingga menghasilkan mikrokapsul minyak ikan. Mikrokapsul dari proses spray drying dianalisis stabilitasnya terhadap oksidasi dengan analisis bilangan peroksida seperti metode pada penelitian Anwar et al. (2011). Analisis ini dilakukan sesaat setelah proses produksi dan selama uji penyimpanan pada suhu ruang selama 8 hari.

\section{Analisis kandungan Glukomanan dengan Mannosa Phenylhydrazone Method (Ohtsuki, 1968).}

Tepung porang sebanyak $1 \mathrm{~g}$ dimasukkan kedalam erlenmeyer, kemudian ditambahkan $50 \mathrm{~mL}$ $\mathrm{HCl} 2 \%$. Pada erlenmeyer dipasang pendingin balik dan dididihkan selama 3 jam kemudian didinginkan dan disaring. Filtrat dinetralkan dengan $\mathrm{NaOH}$ dan ditambahkan arang aktif, lalu disaring lagi.Filtrat didestilasi sampai volume $10 \mathrm{~mL}$. Ke dalam filtrat tersebut ditambahkan $0,4 \mathrm{~g}$ phenylhydrazine hydrochloride dan $0,65 \mathrm{~g} \mathrm{Na}$-asetat dalam $5 \mathrm{~mL}$ aquades. Larutan disimpan dalam lemari es selama 24 jam. Kristal mannosa phenylhydrazine yang terbentuk disaring dan ditimbang.

Perhitungan :

Kadar glukomanan $(\%)=(2 / 3 \times$ a $) /($ berat tepung $-\mathrm{b})$ x $100 \%$

Keterangan :

2/3 : faktor konversi mannosa phenylhydrazine ke manosa total

a : berat kristal mannosa phenylhydrazine

b : berat air dalam tepung porang

Pengukuran Emulsifying Activity Coarse Emulsiondengan Metode Sentrifugasi (VasquezOvando et al., 2013; Wu ,2001).

Sampel sebanyak $10 \mathrm{~mL}$ dimasukkan ke dalam tabung sentrifus, kemudian disentrifugasi pada kecepatan $4500 \mathrm{rpm}$ selama 5 menit. Sentrifugasi dilakukan pada suhu suang, lalu diukur volume krim yang terpisah dan dibandingkan dengan volume emulsi awal. Rumus untuk menghitung Emulsifying Activity adalah:

$\mathrm{EA}=(\mathrm{V} / \mathrm{Vo}) \mathrm{x} 100 \%$

Keterangan :

$\mathrm{EA}=$ Emulsifying Activity

Vo $=$ Volume emulsi sebelum sentrifugasi $(\mathrm{mL})$

$\mathrm{V}=$ Volume lapisan krim setelah sentrifugasi $(\mathrm{mL})$

\section{Pengukuran Stabilitas Fine Emulsion dengan nilai Creaming Index (CI)}

Sampel sebanyak $10 \mathrm{~mL}$ dimasukkan ke dalam tabung penyimpanan berskala dan bertutup 
lalu disimpan pada suhu ruang. Setiap hari diamati pemisahan emulsi yang terjadi, dengan mengukur volume lapisan bening di dasar tabung dan volume emulsi (krim) diatasnya. Nilai CI dihitung menggunakan rumus creaming index menurut McClement (2005).

$\mathrm{CI}=\mathrm{H}_{\mathrm{S}} / \mathrm{H}_{\mathrm{E}} \mathrm{x} 100 \%$

Keterangan :

$\mathrm{CI}=$ Creaming Index

$\mathrm{H}_{\mathrm{S}}=$ Tinggi lapisan bening $(\mathrm{mL})$

$\mathrm{H}_{\mathrm{E}}=$ Tinggi emulsi awal sebelum sentrifugasi $(\mathrm{mL})$

\section{HASIL DAN PEMBAHASAN}

Sebelum diaplikasikan pada proses pembuatan emulsi, tepung porang dianalisis terlebih dahulu. Karakteristik tepung porang yang digunakan berwarna kuning dan tidak berbau dengan kadar air $7,75 \%$, kadar abu $8 \%$, kadar serat 9,72\%, kadar lemak 0,43\%, dan kadar glukomanan 55\%.

\section{Coarse Emulsion}

\section{Kestabilan Emulsi dengan Metode Sentrifugasi}

Uji ini pada prinsipnya merupakan uji akselerasi penyimpanan emulsi. Stabilitas emulsi diukur dengan membandingkan persentase rasiovolume lapisan krim setelah sentrifugasi dengan volume emulsi sebelum sentrifugasi. Perbandingan rasio ini disebut dengan emulsifying activity (EA) (Wu, 2001). Semakin tinggi emulsifying activity menunjukkan pemisahan krim dari emulsi semakin sedikit, sehingga sistem emulsi yang dihasilkanlebih stabil.

Nilai EA yang dihasilkan berkisar antara 56,5\%-100\% dengan rata-rata 87,4\%. Hasil sidik ragam menunjukkan bahwa semua perlakuan, yaitu konsentrasi tepung porang, konsentrasi minyak dan interaksi antara konsentrasi tepung porang (T) dan konsentrasi minyak $(\mathrm{M})$ berpengaruh sangat nyata $(\mathrm{P} \leq 0,01)$ terhadap nilai EA emulsi yang dihasilkan. Pengaruh interaksi antara konsentrasi tepung porang (T) dan konsentrasi minyak (M) terhadap EA dapat dilihat pada Gambar 1.

Gambar 1 menunjukkan bahwa nilai EA terendah diperoleh dari konsentrasi tepung porang $0,5 \%$ dengan konsentrasi minyak 20\%. Pada konsentrasi tepung porang $1 \%$ dan minyak $20 \%$, $30 \%$ dan $40 \%$ nilai EA adalah $100 \%$ artinya tidak terjadi pemisahan emulsi. Untuk konsentrasi tepung porang $0,5 \%$, semakin tinggi konsentrasi minyak yang ditambahkan, maka nilai EA semakin tinggi. Hal ini diduga karena semakin tinggi konsentrasi minyak maka viskositas emulsi juga semakin meningkat sehingga emulsi yang dihasilkan semakin kental dan stabil.

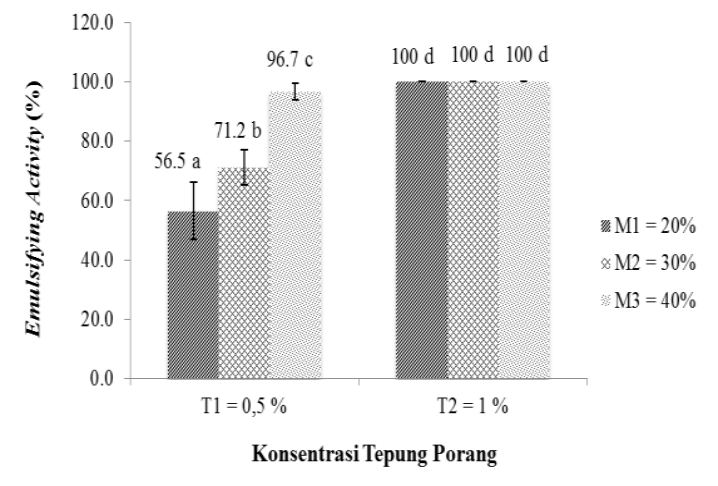

Gambar 1. Pengaruh konsentrasi tepung porang dan konsentrasi minyak terhadap emulsifying activity (nilai yang diikuti huruf yang sama menunjukkan perbedaan yang tidak nyata)

Penelitian ini menghasilkan emulsi dengan kestabilan tertinggi (EA 100\%) pada konsentrasi tepung porang $1 \%$ dan penambahan minyak yang paling banyak $(40 \%)$ atau emulsi dengan viskositas tertinggi. Menurut Dokic el al.(2012), semakin tinggi konsentrasi fase terdispersi dalam sistem emulsi, semakin lambat terjadinya pemisahan krim. Selain itu, hal ini juga sesuai dengan teori yang dikemukakan oleh Dickinson dan Golding (1997) yang menyatakan bahwa peningkatan konsentrasi minyak dalam jumlah besar akan meningkatkan kestabilan krim yang terbentuk melalui peningkatan densitas dan kerapatan droplet minyak.

\section{Uji Viskositas}

Viskositasemulsi yang diperoleh berkisar antara 168-3647cP dengan rata-rata $1340 \mathrm{cP}$. Hasil sidik ragam menunjukkan bahwa semua perlakuan berpengaruh sangat nyata $(\mathrm{P} \leq 0,01)$ terhadap viskositas yang dihasilkan. Pengaruh interaksi antara konsentrasi tepung porang (T) dan konsentrasi minyak (M) terhadap viskositas dapat dilihat pada Gambar2.

Gambar 2 menunjukkan bahwa nilai viskositas tertinggi dihasilkan pada konsentrasi tepung porang $1 \%$ dengan konsentrasi minyak $40 \%$,viskositas paling rendah terdapatpada konsentrasi tepung porang $0,5 \%$ dengan konsentrasi minyak $20 \%$ dan $30 \%$. Semakin tinggi konsentrasi tepung porang dan minyak yang ditambahkan, maka semakin tinggi pula viskositas emulsi yang dihasilkan. Pada sistem emulsi $\mathrm{m} / \mathrm{a}$, penambahan tepung porang akan meningkatkan viskositas sehingga dapat membentuk sistem emulsi yang lebih stabil.

Viskositas tertinggi terukur pada emulsi dengan konsentrasi tepung porang $1 \%$ dan konsentrasi minyak $40 \%$. Hal ini diduga karena sifat glukomanan yang terkandung dalam tepung porang sangat mudah larut dalam air dan membentuk larutan yang sangat kental (gel)yang stabil dan tidak mudah 
rusak (Mulyono, 2009; Sumarwoto, 2007). Semakin banyak tepung porang yang ditambahkan maka viskositas yang dihasilkan semakin tinggi. Selain itu, semakin tinggi konsentrasi minyak yang digunakan maka air yang di tambahkan semakin sedikit sehingga emulsi yang terbentuk akan semakin kental.

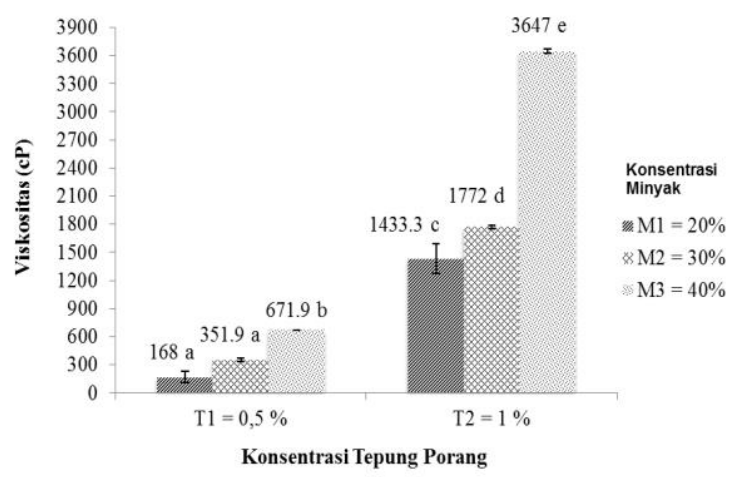

Gambar 2. Pengaruh konsentrasi tepung porang dan konsentrasi minyak terhadap viskositas(nilai yang diikuti huruf yang sama menunjukkan perbedaan yang tidak nyata)

Peningkatan viskositas emulsi dapat dipengaruhi oleh jumlah droplet-droplet minyak di dalam air. Untuk menghasilkan emulsi yang stabil, permukaan droplet minyak harus dilapisi oleh emulsifier sehingga minyak dapat terdispersi didalam air (Marie et al., 2002). Selain itu, peningkatan konsentrasi total padatan (tepung porang, minyak dan surfaktan) juga dapat meningkatkan viskositas emulsi. Tingginya viskositas emulsi akan mempengaruhi lama penyimpanan. Semakin tinggi viskositas, maka sistem emulsi yang dihasilkan semakin stabil selama penyimpanan.

Viskositas emulsi dengan penambahan tepung porang $1 \%$ berbeda signifikan pada ketiga konsentrasi minyak (20\%, 30\% dan 40\%). Semakin besar konsentrasi minyak yang ditambahkan, semakin tinggi viskositas emulsi. Hal ini sesuai dengan hasil penelitian Dokic (2012) yang meneliti kestabilan emulsi m/a pada konsentrasi minyak 5$60 \%$ menggunakan pati OSA sebagai penstabil. Dokic (2012) juga menghasilkan emulsi paling stabil pada konsentrasi minyak tertinggi $(60 \%)$. Kestabilan ini berhubungan dengan kerapatan droplet dalam sistem emulsi.

Seperti halnya pati, glukomanan termasuk kelompok biopolimer yang menstabilkan emulsi dengan mekanisme meningkatkan viskositas fase pendispersi. Peningkatan viskositas ini menyebabkan droplet minyak bergerak sangat terbatas. Jumlah droplet yang banyak atau rapat dalam sistem emulsi dapat dihambat gerakannya oleh glukomanan yang larut dalam air. Interaksi keduanya (kekentalan glukomanan dan konsentrasi minyak yang tinggi) meningkatkan viskositas emulsi secara keseluruhan. Hal inilah yang menyebabkan peningkatan viskositas emulsi secara signifikan seiring dengan bertambahkan konsentrasi fase terlarut (minyak).

\section{Ukuran Droplet Emulsi Secara Mikroskopis}

Analisis ukuran droplet secara mikroskopis bertujuan untuk mengetahui ukuran dan sebaran droplet dalam emulsi (Gambar 3 dan 4). Menurut Flouryet al. (2002), semakin kecil ukuran droplet mengakibatkan peningkatan stabilitas emulsi karena jumlah droplet yang terdispersi dalam air semakin banyak. Uji secara mikroskopis ini juga menunjukkan kerapatan droplet-droplet minyak dan distribusi ukuran droplet yang terbentuk.

Gambar 3a dan 4a menunjukkan bahwa tepung porang larut sempurna dalam air yang dilihat dengan pembesaran 40x. Secara keseluruhan, Gambar 3 dan 4 menunjukkan bahwa semakin tinggi konsentrasi minyak yang digunakan maka semakin meningkat jumlah droplet yang dihasilkan serta distribusi droplet juga semakin merata.Hasil penelitian ini sesuai dengan penelitian Raymundo et al. (2001) yang menyebutkan bahwa penggunaan konsentrasi minyak yang tinggi dapat meningkatkan jumlah droplet yang terbentuk.

Menurut McClements et al. (2005), ketidakstabilan emulsi secara fisik yaitu creaming dan sedimentasi dapat terjadi akibat pemisahan gravitasi. Flokulasi dan koalesen dapat terjadi akibat penyatuan atau agregasi droplet. Berdasarkan Gambar 3b dan 4b diketahui bahwa terjadi ketidakstabilan emulsi karena adanya flokulasi yaitu terjadinya penyatuan dua atau lebih droplet membentuk suatu agregat droplet yang lebih besar. Gambar 3c dan 4c menunjukkan emulsi yang kurang stabil karena terjadinya flokulasi dan koalesen yang lebih banyak dibandingkan dengan Gambar 3b Sedangkan pada Gambar 3d dan 4d, droplet minyak menyebar relatif lebih merata dengan ukuran yang lebih seragam dan tidak banyak mengalami penyatuan droplet.

Semakin kecil ukuran partikel droplet minyak maka penyebarannya dalam air semakin meningkat sehingga emulsi lebih stabil. Selain itu, penggunaan tepung porang yang mengandung glukoman dapat meningkatkan viskositas larutan sehingga droplet minyak yang dihasilkan tidak dapat menyatu dengan cepat dengan droplet lainnya karena pergerakannya yang terbatas. 


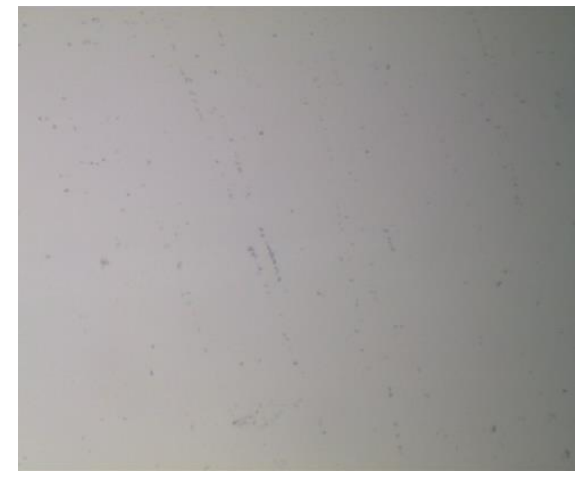

(a)

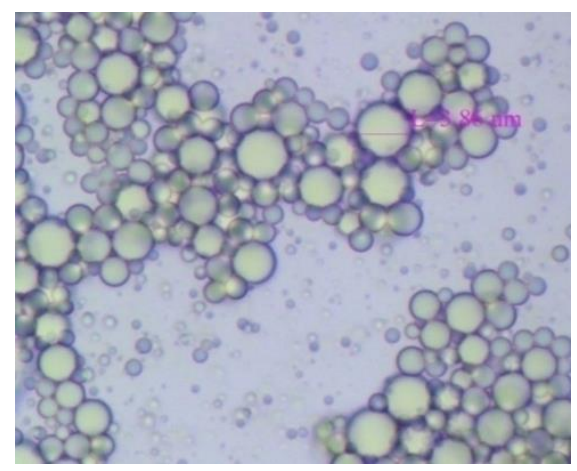

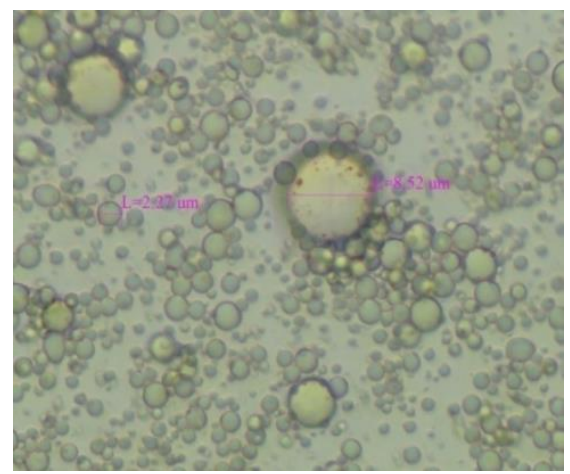

(b)

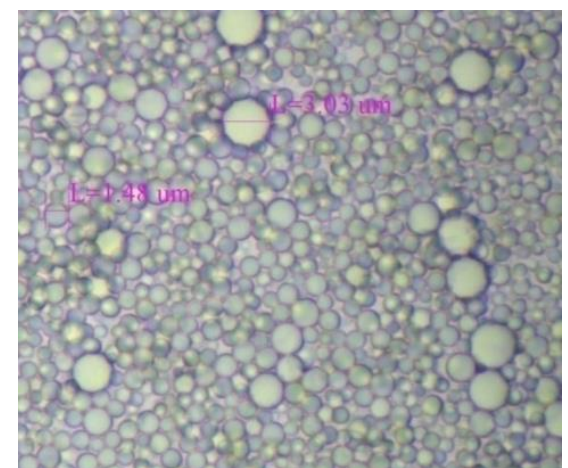

Gambar 3.(a) Larutan tepung porang0,5\%; emulsi dengan konsentrasi tepung porang $1 \%$ dan: (b) konsentrasi minyak 20\%; (c) konsentrasi minyak 30\%; (d) konsentrasi minyak $40 \%$

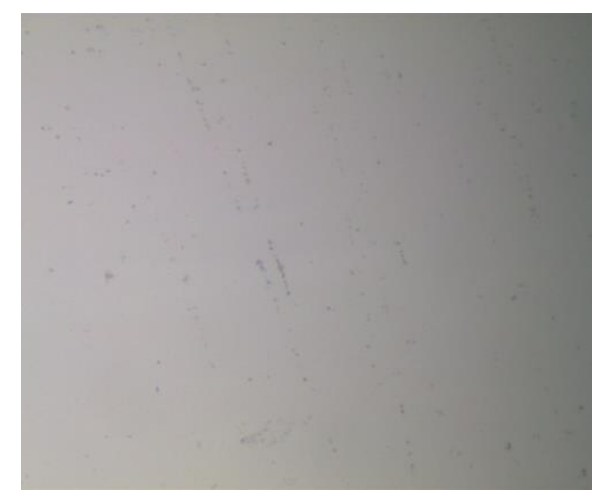

(a)

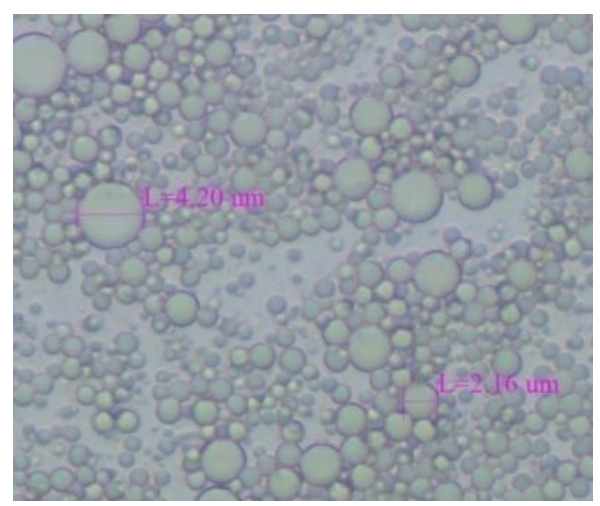

(c)

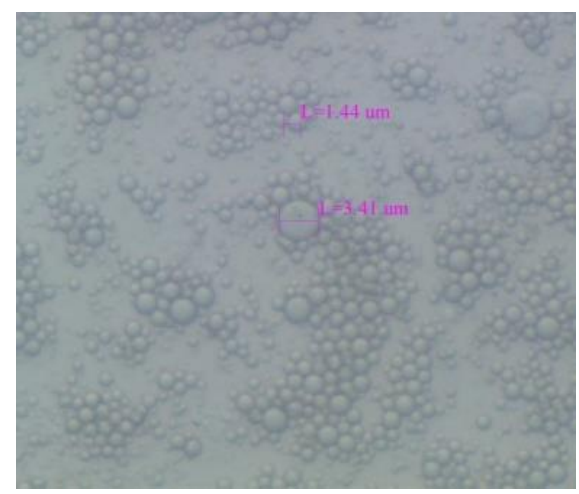

(b)

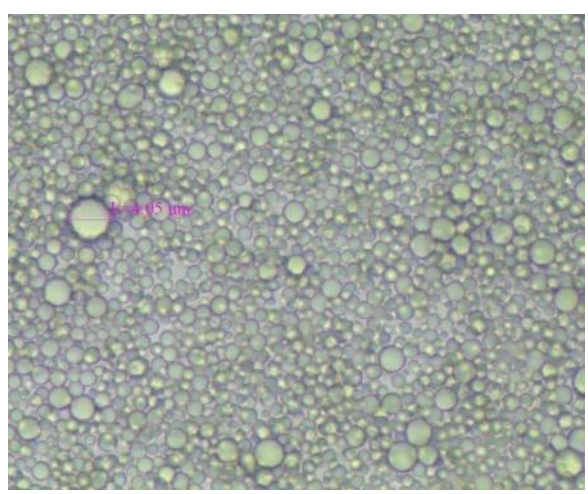

(d)

Gambar 4. (a) Larutan tepung porang1\%; emulsi dengan konsentrasi tepung porang $1 \%$ dan: (b) konsentrasi minyak 20\%; (c) konsentrasi minyak 30\%; (d) konsentrasi minyak $40 \%$ 


\section{Batas-Batas Lapisan yang Terpisah Selama Penyimpanan}

Analisis ini digunakan untuk mengamati keadaan emulsi selama satu minggu dan mengetahui penyebab ketidakstabilan emulsi. Uji ini sangat berguna untuk mengetahui pengaruh parameter seperti kekuatan ionik, $\mathrm{pH}$ atau penambahan biopolimer atau surfaktan pada stabilitas emulsi. Tinggi batas-batas lapisan yang terpisah selama penyimpanan dapat dilihat pada Gambar 5.

Gambar 5 menunjukkan bahwa pada berbagai variasi konsentrasi minyak $(20 \%, 30 \%$ dan $40 \%$ ), pemisahan emulsi yang terjadi lebih tinggi pada konsentrasi tepung porang $0,5 \%$ dibandingkan dengan konsentrasi tepung porang $1 \%$. Hal ini disebabkan karena penambahan tepung porang sangat berperan dalam meningkatkan viskositas emulsi sehingga berpengaruh dalam penyimpanan. Semakin tinggi konsentrasi tepung porang yang digunakan maka semakin tinggi viskositas emulsi yang dihasilkan sehingga emulsi semakin stabil (Intan et al., 2012).

\section{Fine Emulsion}

Berdasarkan hasil uji stabilitas coarse emulsion, emulsi yang lebih stabil diperoleh dari kombinasi tepung porang $0,5 \%$ dan $1 \%$ dengan konsentrasi minyak $30 \%$ dan $40 \%$. Adapun emulsi dengan penambahan minyak $20 \%$ memiliki stabilitas yang paling rendah. Oleh karena itu, pembuatan fine emulsion hanya menggunakan 2 variabel yang masing-masing terdiri dari 2 faktor, yaitu konsentrasi tepung porang $0,5 \%$ dan $1 \%$ serta konsentrasi minyak $30 \%$ dan $40 \%$ dengan dua kali ulangan.

\section{Pengukuran Ukuran Partikel, Indeks Polidispersitas, dan Zeta Potensial}

Karakterisasi emulsi meliputi pengukuran distribusi ukuran partikel, indeks polidispersitas dan kestabilan partikel berdasarkan nilai zeta potensial. Hasil karakterisasi emulsi yang dihasilkan pada penelitian ini dapat dilihat pada Tabel 1 .

Tabel 1 menyajikan tentang ukuran partikel, indeks polidispersitas dan zeta potensial emulsi berdasarkan konsentrasi tepung porang dan konsentrasi minyak ikan. Berdasarkan ukuran partikel emulsi, tampak adanya pengaruh dari konsentrasi tepung porang dan minyak ikan. Semakin besar konsentrasi tepung porang dan minyak ikan, ukuran partikel semakin menurun. Ukuran partikel pada emulsi yang menggunakan tepung porang $0,5 \%$ dan minyak $30 \% \quad\left(\mathrm{~T}_{1} \mathrm{M}_{2}\right)$, tepung porang $0,5 \%$ dan minyak $40 \% \quad\left(\mathrm{~T}_{1} \mathrm{M}_{3}\right)$, tepung porang $1 \%$ dan minyak $30 \%\left(\mathrm{~T}_{2} \mathrm{M}_{2}\right)$, tepung porang $1 \%$ dan minyak $40 \%\left(\mathrm{~T}_{2} \mathrm{M}_{3}\right)$ berturut-turut mengalami penurunan dari $1301 \mathrm{~nm}$ menjadi 614 $\mathrm{nm}$.

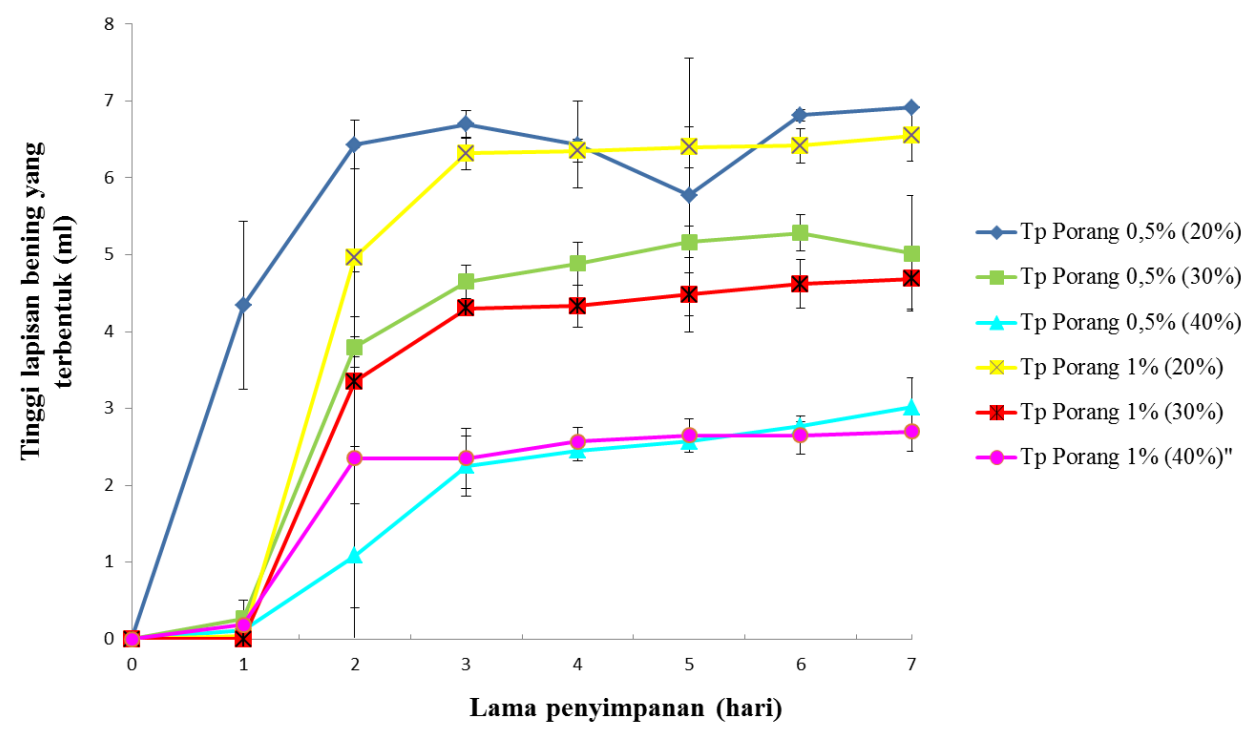

Gambar 5.Tinggi batasan emulsi yang terpisah pada konsentrasi tepung porang $(0,5 \%, 1 \%)$ dankonsentrasi minyak $(20 \%, 30 \%, 40 \%)$

Tabel 1. Ukuran partikel, indeks polidispersitas dan zeta potensial emulsi berdasarkan konsentrasi tepungporang dan konsentrasi minyak ikan

\begin{tabular}{ccccc}
\hline No. & Kode Sampel & Ukuran Partikel $(\mathbf{n m})$ & Indeks Polidispersitas (PdI) & Zeta Potensial (mV) \\
\hline 1 & $\mathrm{~T}_{1} \mathrm{M}_{2}$ & 1301 & 0,344 & $-24,97$ \\
2 & $\mathrm{~T}_{1} \mathrm{M}_{3}$ & 837,7 & 0,167 & $-30,47$ \\
3 & $\mathrm{~T}_{2} \mathrm{M}_{2}$ & 608,1 & 0,255 & $-21,87$ \\
4 & $\mathrm{~T}_{2} \mathrm{M}_{3}$ & 614,0 & 0,237 & $-25,83$ \\
\hline
\end{tabular}


Hal tersebut seiring dengan hasil analisis ukuran partikel secara mikroskopis sebelumnya, yang menunjukkan bahwa droplet minyak menyebar relatif lebih merata dengan ukuran yang lebih seragam dan tidak banyak mengalami penyatuan droplet pada emulsi dengan konsentrasi tepung porang lebih tinggi $(1 \%)$ dan konsentrasi minyak ikan tertinggi (40\%). Semakin kecil ukuran partikel droplet minyak maka penyebarannya dalam air semakin meningkat sehingga emulsi lebih stabil. Selain itu, penggunaan tepung porang yang mengandung glukomanan dapat meningkatkan viskositas larutan sehingga droplet minyak yang dihasilkan tidak dapat menyatu dengan cepat dengan droplet lainnya karena pergerakannya yang terbatas. Indeks polidispersitas mengindikasikan kualitas keseragaman suatu dispersi. Nilai indeks polidispersitas yang kecil menunjukkan distribusi ukuran partikel yang sempit, yang berarti ukuran partikel semakin seragam. Berdasarkan hasil pada Tabel 1 nilai indeks polidispersitas berturut-turut dari yang terbesar 0,344 $\left(\mathrm{T}_{1} \mathrm{M}_{2}\right), 0,255\left(\mathrm{~T}_{2} \mathrm{M}_{2}\right), 0,237$ $\left(\mathrm{T}_{2} \mathrm{M}_{3}\right), 0,167\left(\mathrm{~T}_{1} \mathrm{M}_{3}\right)$. Hal ini menunjukkan bahwa emulsi $\mathrm{T}_{2} \mathrm{M}_{3}$ dengan ukuran partikel $614,0 \mathrm{~nm}$ lebih seragam dibandingkan emulsi $\mathrm{T}_{2} \mathrm{M}_{2}$ dengan ukuran partikel $608,1 \mathrm{~nm}$. Penurunan ukuran partikel dan indeks polidispersitas terjadi seiring dengan peningkatan konsentrasi tepung porang dan konsentrasi minyak ikan.

Penambahan tepung porang dengan konsentrasi yang semakin tinggi, sangat berperan dalam meningkatkan viskositas emulsi. Semakin tinggi konsentrasi tepung porang yang digunakan maka semakin tinggi viskositas emulsi yang dihasilkan sehingga emulsi semakin stabil, droplet minyak menyebar relatif lebih merata dengan ukuran yang lebih seragam dan tidak banyak mengalami penyatuan droplet. Begitu juga dengan semakin tinggi konsentrasi minyak yang digunakan maka semakin meningkat jumlah droplet yang dihasilkan serta distribusi droplet juga semakin merata.

Muatan permukaan zeta potensial menghasilkan gaya tolak listrik diantara droplet minyak yang dapat menghambat penggabungan droplet. Secara umum, partikel dengan nilai zeta potensial melebihi $+30 \mathrm{mV}$ atau kurang dari $-30 \mathrm{mV}$ menunjukkan kestabilan, karena muatan listrik dari droplet cukup kuat untuk menolak antara droplet yang dominan dalam sistem nanoemulsi (Trujillo et al., 2013). Kisaran nilai zeta potensial yang dihasilkan keempat emulsi pada penelitian ini ($21,87)$ - $(-30,47) \mathrm{mV}$. Nilai zeta potensial yang kurang dari $-30 \mathrm{mV}$ dimiliki oleh tiga dari empat emulsi yang dianalisis yaitu $\mathrm{T}_{1} \mathrm{M}_{2}, \mathrm{~T}_{2} \mathrm{M}_{2}, \mathrm{~T}_{2} \mathrm{M}_{3}$. Dari data ketiga emulsi yang dikatakan stabil dalam penelitian ini, ukuran partikel terkecil dengan indeks polidispersitas yang kecil dan nilai zeta potensial melebihi $+30 \mathrm{mV}$ atau kurang dari $-30 \mathrm{mV}$ dimiliki oleh emulsi dengan konsentrasi tepung porang $1 \%$ dan konsentrasi minyak $40 \%\left(\mathrm{~T}_{2} \mathrm{M}_{3}\right)$.

\section{Bentuk Droplet dengan Transmission Electron Microscope (TEM)}

Untuk melihat bentuk dan sebaran droplet emulsi yang paling stabil, penelitian ini juga membandingkan hasil yang diperoleh dengan melihat sampel emulsi $\mathrm{T}_{2} \mathrm{M}_{3}$ dibawah transmission electron microscope (Gambar 6).

Gambar 6a memperlihatkan bentuk droplet emulsi yang relatif bulat diamati dengan pembesaran $37000 \mathrm{x}$ dimana garis merah mewakili skala $200 \mathrm{~nm}$. Droplet minyak dikelilingi oleh lingkaran hitam yang diduga merupakan lapisan surfaktan (tween 80) yang terserap pada permukaan interfacial membrane. Hal ini mirip dengan lapisan hitam protein yang mengelilingi droplet minyak pada penelitian Fernandez-Avila dan Trujillo (2016).

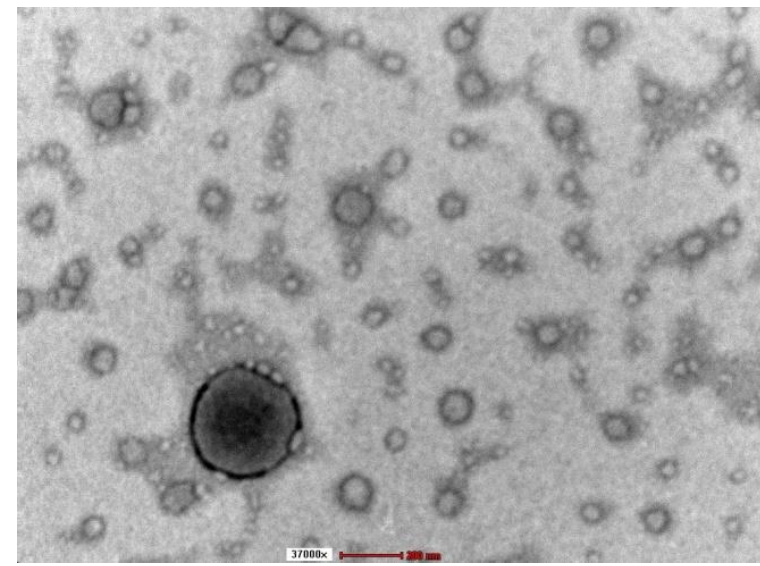

(a)

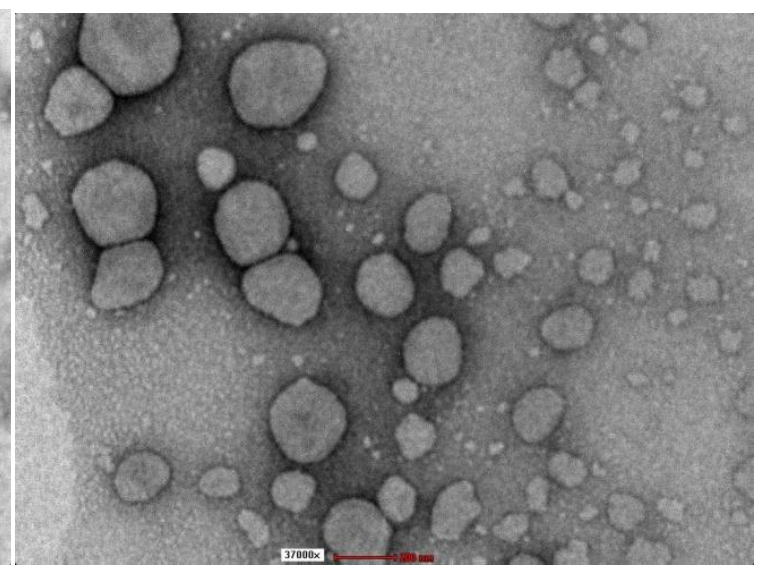

(b)

Gambar 6. Bentuk dan sebaran droplet dari emulsi $\mathrm{T}_{2} \mathrm{M}_{3}$ dilihat dengan transmission electron microscope 
Adapun partikel-partikel kecil tersebar di sekitar droplet yang berukuran kurang dari $50 \mathrm{~nm}$ diduga merupakan tepung porang yang tidak dapat larut sempurna dalam fase pendispersi (air). Partikel ini juga terlihat pada lapisan luar droplet minyak (interface).Tepung porang yang larut sempurna berfungsi meningkatkan viskositas fase pendispersi sehingga droplet sulit bergerak bebas. Hal ini menjelaskan mekanisme penstabilan ganda yang diberikan oleh surfaktan dan tepung porang. Gambar $6 \mathrm{~b}$ menunjukkan ukuran droplet minyak yang bervariasi diamati pada pembesaran yang sama. Droplet minyak juga terlihat dikelilingi oleh lapisan hitam namun lebih tipis dibandingkan dengan Gambar 6a.

\section{Kestabilan Fine Emulsion Selama Penyimpanan}

Emulsi disimpan pada suhu ruang dan diamati volume lapisan yang terpisah yaitu terbentuknya lapisan bening di dasar wadah dan krim dibagian atasnya. Pengamatan dilakukan setiap hari selama 16 hari. Hasil pengamatan dikonversi menjadi nilai creaming index (CI) dengan rumus yang telah disebutkan sebelumya dan hasilnya dapat dilihat pada Gambar 7.

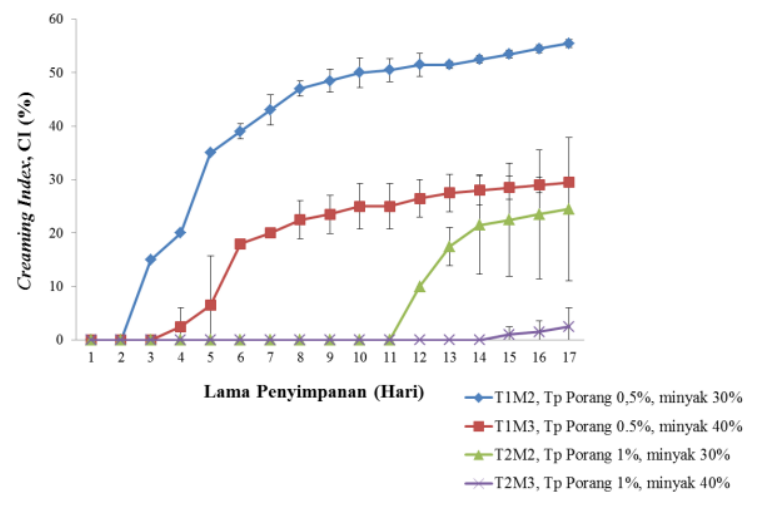

Gambar 7. Nilai creaming index dari fine emulsion selama penyimpanan suhu ruang
Gambar 7 menunjukkan bahwa konsentrasi tepung porang dan minyak sangat menentukan kestabilan emulsi. Pada tingkat kombinasi tepung $0,5 \%$ dan minyak $30 \%\left(\mathrm{~T}_{1} \mathrm{M}_{2}\right)$, emulsi hanya bertahan selama 2 hari dan pada hari ke-3 emulsi mulai terpisah yang ditandai dengan meningkatnya nilai CI hingga 55,5\% di akhir masa penyimpanan. Peningkatan konsentrasi minyak menjadi $40 \%$ $\left(\mathrm{T}_{1} \mathrm{M}_{3}\right)$ mampu menunda pemisahan menjadi 4 hari meskipun peningkatan nilai CI terus bertambah mencapai $29,5 \%$. Kombinasi tepung porang $1 \%$ dan minyak 30\% menghasilkan emulsi yang tetap homogen selama 12 hari. Emulsi yang paling stabil diperoleh dari kombinasi tepung porang $1 \%$ dan minyak $40 \%$ dimana tidak terjadi pemisahan sama sekali selama 13 hari dan nilai CI meningkat hanya $2,5 \%$ di hari ke-16. Semakin tinggi konsentrasi tepung porang dan minyak yang ditambahkan, semakin stabil emulsi yang dihasilkan.

Perbedaan kestabilan yang cukup signifikan dari coarse emulsion (Gambar 5) dan fine emulsion (Gambar 7) ini dipengaruhi oleh metode emulsifikasi yang digunakan. Pengecilan ukuran droplet emulsi karena proses homogenisasi tingkat dua oleh high pressure homogenizer (HPH) sangat menentukan kestabilan emulsi. Emulsi yang dihomogenisasi dengan ultra turrax saja hanya mampu bertahan maksimal dua hari sedangkan yang mengalami 2 tahap homogenisasi dapat homogen selama 13 hari tanpa pemisahan.

Visualisasi stabilitas emulsi selama penyimpanan juga dapat dilihat pada Gambar 8 . Pada prinsipnya, Gambar 7 dan 8 adalah sama, pada Gambar 7 stabilitas dinyatakan dengan nilai CI (\%) sedangkan Gambar 8 memperlihatkan volume (dalam $\mathrm{mL}$ ) lapisan bening (serum layer) didasar tabung penyimpanan dan lapisan krim di atasnya (emulsion layer). Di akhir masa simpan, kondisi emulsi yang terpisah dapat dilihat dalam bentuk foto.

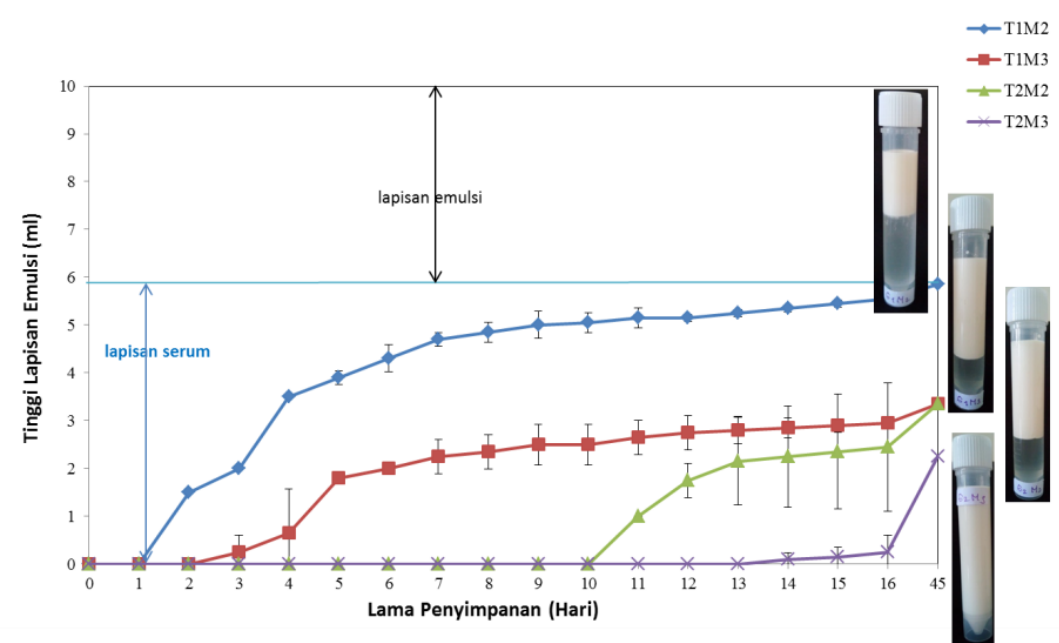

Gambar 8. Pemisahan emulsi selama penyimpanan dengan melihat volume lapisan bening dankrim yang terbentuk 
Emulsi yang paling tidak stabil adalah yang dibuat dari $0,5 \%$ tepung porang dan $30 \%$ minyak $\left(\mathrm{T}_{1} \mathrm{M}_{2}\right)$ yang ditandai dengan terbentuknya $6 \mathrm{~mL}$ lapisan serum pada hari ke-45. Peningkatan konsentrasi minyak menjadi $40 \%$ dapat mengurangi volume lapisan bening yang terbentuk hingga separuhnya ( $3 \mathrm{~mL}$, di hari ke-45). Tambahan tepung porang menjadi $1 \%$ ternyata mampu menstabilkan emulsi tanpa lapisan bening selama 10 hari meskipun selanjutnya terjadi pemisahan. Konsentrasi tepung porang $1 \%$ dan minyak $40 \%$ juga terbukti yang paling stabil dengan tidak adanya lapisan bening sama sekali di hari ke-13.

Fine emulsion jauh lebih stabil dibandingkan coarse emulsion utamanya disebabkan oleh pemecahan droplet dari coarse emulsion oleh dorongan piston untuk memasuki celah sempit pada alat HPH. Dorongan piston yang bertekanan tinggi dapat memecah droplet minyak menjadi dropletdroplet berukuran sangat kecil (Lee dan Norton, 2013). Semakin kecil ukuran droplet minyak maka semakin stabil emulsi yang dihasilkan. Selain itu, droplet-droplet kecil ini sulit bergerak karena berada pada fase kontinyu (larutan glukomanan) dengan viskositas tinggi.

\section{Produksi Mikrokapsul Menggunakan Spray Dryer}

Emulsi yang paling stabil pada penelitian ini adalah $\mathrm{T}_{2} \mathrm{M}_{3}$, namun karena viskositasnya paling tinggi maka emulsi ini sulit untuk dikeringkan menggunakan spray dryer. Emulsi yang terlalu kental dan tidak mudah mengalir sulit untuk dikeringkan dan menyebabkan tersumbatnya nozzle pada spray dryer. Oleh karena itu, emulsi $\mathrm{T}_{1} \mathrm{M}_{2}$ (konsentrasi tepung porang $0,5 \%$ dan minyak ikan $30 \%$ ) dipilih untuk menghasilkan mikrokapsul minyak ikan. Pemilihan emulsi $\mathrm{T}_{1} \mathrm{M}_{2}$ ini didasarkan pada kemudahan proses pengeringan emulsi dengan spray dryer. Viskositas emulsi $\mathrm{T}_{1} \mathrm{M}_{2}$ masih dapat ditolerir untuk proses mikroenkapsulasi.

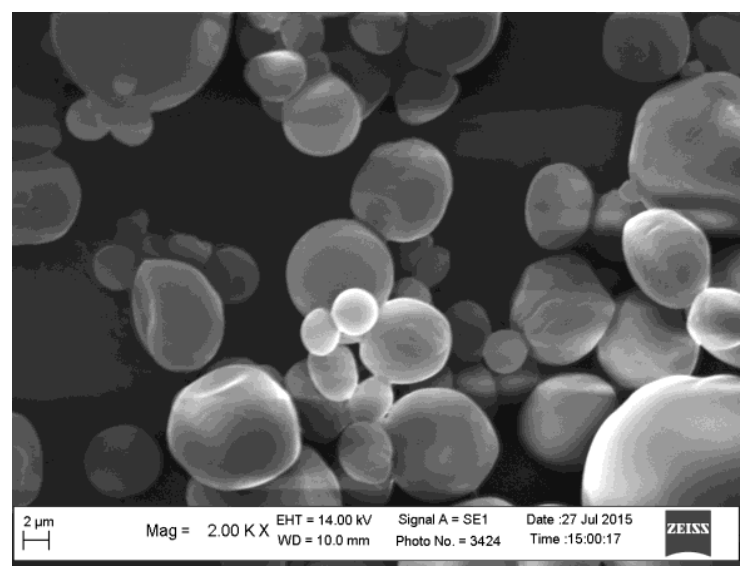

Gambar 9. Hasil SEM mikrokapsul minyak ikan dari emulsi $\mathrm{T}_{1} \mathrm{M}_{2}$
Mikrokapsul yang dihasilkan merupakan serbuk putih seperti tepung dengan kandungan minyak ikan 30\%. Hasil scanning electron microscope (SEM) mikrokapsul dapat dilihat pada Gambar 9. Bentuk mikrokapsul umumnya adalah bulat seperti bola meskipun ada pula mikrokapsul dengan cekungan pada permukaannya. Secara umum bagian permukaan mikrokapsul terlihat mulus dengan ukuran bervariasi antara 2-10 $\mu \mathrm{m}$. Halusnya permukaan mikrokapsul diduga karena emulsi yang mengandung glukomanan yang bersifat membentuk gel jika dilarutkan dalam air. Sifat glukomanan yang menstabilkan emulsi dengan mekanisme meningkatkan viskositas fase kontinyu diduga mempengaruhi karakteristik fisik mikrokapsul minyak ikan yang dihasilkan.

\section{Kestabilan Mikrokapsul Terhadap Oksidasi Selama Penyimpanan}

Untuk melihat tingkat kestabilan minyak ikan yang dikandung oleh mikrokapsul selama penyimpanan pada suhu ruang, dilakukan pengukuran bilangan peroksida (PV). Uji ini mendeteksi pembentukan hidroperoksida yang merupakan hasil oksidasi tingkat pertama. Mikrokapsul disimpan dalam botol kaca tertutup selama 8 hari pada suhu ruang. Nilai PV diukur setiap hari selama periode penyimpanan tersebut. Hasil pengukuran dapat dilihat pada Gambar 10.

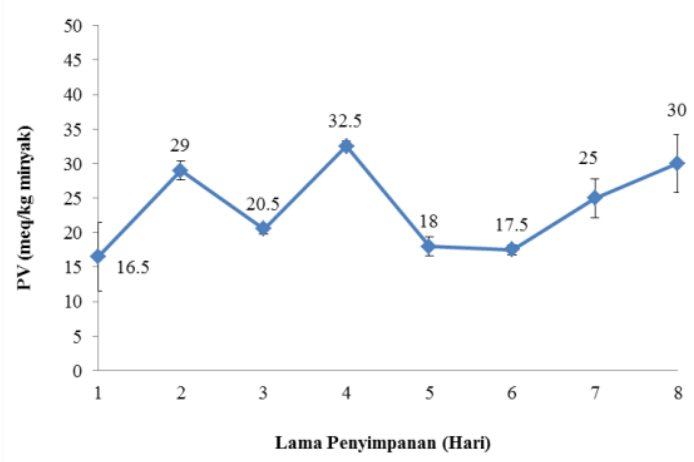

Gambar 10. Hasil pengukuran nilai PV dari mikrokapsul minyak ikan

Nilai PV yang diperoleh berdasarkan grafik pada Gambar 10 menunjukkan hasil yang berfluktuasi dengan kisaran 16.5 - $32.5 \mathrm{meq} / \mathrm{kg}$ minyak. Nilai PV tertinggi diperoleh pada penyimpanan setelah 4 hari kemudian menurun dan meningkat kembali di akhir masa penyimpanan. Nilai PV maksimum pada penelitian ini tidak mencapai nilai $35 \mathrm{meq} / \mathrm{kg}$ minyak namun cukup signifikannya nilai PV ini diduga karena minyak ikan sudah mulai teroksidasi pada saat proses pengeringan menggunakan spray dryer. Proses ini membutuhkan waktu yang cukup lama (2-4 jam) dan menggunakan suhu pengeringan melebihi $100^{\circ} \mathrm{C}$, yaitu $150-160^{\circ} \mathrm{C}$. Ekspos minyak ikan dengan kandungan asam lemak tidak jenuh yang tinggi pada 
suhu melebihi $100^{\circ} \mathrm{C}$ dapat memicu terjadinya proses oksidasi secara cepat.

Pengukuran bilangan peroksida untuk mengukur tingkat oksidasi lipida pada bahan pangan dilaporkan sebagai metode yang kurang sensitif oleh Frankel (2005) khususnya jika sampel sudah terekspos pada panas dan cahaya seperti mikrokapsul pada penelitian ini. Berfluktuasinya nilai PV pada Gambar 10 diduga karena peroksida yang terbentuk bersifat sangat labil dan reaktif. Jika oksidasi berlanjut, peroksida yang sangat labil ini dengan cepat akan terdegradasi baik secara enzimatik maupun non-enzimatik membentuk produk oksidasi tingkat kedua yang lebih kompleks seperti aldehida dan keton (Pegg, 2005). Peningkatan nilai PV yang cukup signifikan menandakan kecepatan pembentukan peroksida melebihi kecepatan degradasinya dan sebaliknya. Oleh karena itu jika nilai PV menurun setelah sebelumnya meningkat, hal ini berarti telah terjadi oksidasi lanjutan pada sampel yaitu terurainya peroksida menjadi aldehida dan keton. Aldehida dan keton adalah indikator telah terbentuknya rancidity pada sampel.

Selain itu hasil penelitian Anwar et al. (2011) menunjukkan bahwa kestabilan mikrokapsul sangat dipengaruhi oleh kombinasi bahan penyalut yang digunakan dan metode pengeringan mikrokapsul tersebut. Pada metode pengeringan yang sama yaitu menggunakan spray dryer, mereka berhasil menekan nilai PV hingga dibawah 10 meq/kg minyak di akhir minggu pertama penyimpanan. Mereka menggunakan kombinasi maltodekstrin, polisakarida dari kedelai yang larut dalam air, pati modifikasi dan hydroxypropyl betacyclodextrin sebagai bahan penyalut. Nilai PV pada penelitian ini mencapai nilai maksimum yaitu $32,5 \mathrm{meq} / \mathrm{kg}$ minyak pada hari ke-4 penyimpanan. Perbedaan hasil ini diduga karena perbedaan penggunaan bahan penyalut dalam pembuatan mikrokapsul minyak ikan, yaitu penggunaan tepung porang dengan bantuan tween 80 sebagai surfaktan.

Penelitian terbaru yang dilakukan oleh Wang et al.(2016) tentang mikroenkapsulasi $10 \%$ minyak ikan menggunakan protein sebagai bahan penyalut membuktikan bahwa efisiensi enkapsulasi belum dapat mencapai $100 \%$. Nilai bilangan peroksida (PV) mikrokapsul mendekati $20 \mathrm{meq} / \mathrm{kg}$ minyak setelah disimpan 40 hari pada $40^{\circ} \mathrm{C}$ dan mencapai 60 meq/kg minyak setelah 50 hari penyimpanan. Kandungan minyak ikan dalam mikrokapsul pada penelitian Wang et al.(2016) hanya $10 \%$ dibandingkan dengan mikrokapsul pada penelitian ini yang mencapai $30 \%$.

\section{KESIMPULAN DAN SARAN}

Semua perlakuan yaitu konsentrasi tepung porang, konsentrasi minyak dan interaksi antara konsentrasi tepung porang $(\mathrm{T})$ dan konsentrasi minyak (M) berpengaruh sangat nyata $(\mathrm{P} \leq 0,01)$ terhadap nilai emulsifying activity (EA) dan viskositas. Nilai viskositas coarse emulsion tertinggi dihasilkan dari konsentrasi tepung porang $1 \%$ dan konsentrasi minyak 40\%. Perlakuan terbaik untuk coarse emulsion adalah konsentrasi glukomanan $1 \%$ dengan konsentrasi minyak $40 \%$, dengan viskositas $3647 \mathrm{cp}$, emulsifying activity 100\%, pemisahan serum 2,70 $\mathrm{mL}$ setelah 7 hari penyimpanan, penyebaran droplet minyak relatif merata dan terjadinya flokulasi dan koalesen dapat diminimalkan.

Fine emulsion terbaik diperoleh dengan kombinasi perlakuan yang sama dimana emulsi dapat disimpan selama 16 hari dengan pemisahan minimal hanya $0,25 \mathrm{~mL}$, nilai $\mathrm{CI}$ pada hari ke 16 adalah 2,5\%, ukuran rata-rata droplet $614 \mathrm{~nm}$, nilai PdI 0,237, dan zeta potential $-25,83 \mathrm{mV}$. Stabilitas emulsi $\mathrm{m} / \mathrm{a}$ pada penelitian ini diperoleh melalui mekanisme penstabilan ganda yang diberikan oleh oleh surfaktan (tween 80) bersama-sama dengan partikel tepung porang pada lapisan luar droplet minyak serta peningkatan viskositas fase pendispersi oleh tepung porang yang larut dalam air.Hal ini dibuktikan dengan hasil pengamatan menggunakan TEM. Nilai PV yang diperoleh selama 8 hari penyimpanan mikrokapsul minyak ikan berkisar antara $16.5-32.5 \mathrm{meq} / \mathrm{kg}$ minyak.

\section{DAFTAR PUSTAKA}

Ali DY, Darmadji P, dan Pranoto Y. 2014. Optimasi nanoenkapsulasi asap cair tempurung kelapa dengan Response Surface Methodology dan karakterisasi nanokapsul. J Teknol Indus Pangan. 25(1): 23-30.

Aljamali NM. 2015. Zetasizer technique in biochemistry. Biochem Anal Biochem. 4(2): $1-5$

Anwar SH dan Kunz B. 2011. The influence of drying methods on the stabilization of fish oil microcapsules: Comparison of spray granulation, spray drying, and freeze drying. J Food Eng. 105(2): 367-378.

Charoen R, Jangchud A, Jangchud K, Harnsilawat T, Naivikul O, McClements DJ. 2011. Influence of biopolymer emulsifier type on formation and stability of rice branoil-inwater emulsions: whey protein, gumarabic, and modified starch. J Food Sci. 76(1): E165-E172.

Dickinson E dan Golding M. 1997. Rheology of sodium caseinate stabilized oil inwater emulsions. J Colloid Interface Sci. 191:166176.

Dokic LV, Krstonosic I, dan Nikolic. 2012. Physicochemical characteristics and stability of oil in water emulsions stabilized by OSA starch. Food Hydrocoll.29: 185192. 
Fernandez-Avila C dan Trujillo AJ. 2016. Ultra-high pressure homogenization improves oxidative stability and interfacial properties of soy protein isolate-stabilized emulsions. Food Chem. (209): 104-113.

Flores CF, Ribeiro RF, Ourique AF, Silva CMB. 2011. Nanostructured systems containing an essential oil: protection against volatilization. Quim. Nova. 34(6): 968-972.

Floury J, Desrumaux A, dan Legrand J. 2002. Effect of ultra-high pressure homogenization on structure and on rheological properties of soy protein-stabilized emulsions. J Food Sci. 67 (9): 3388-3395.

Frankel EN. 2005. Lipid Oxidation. Bridgwater, England: The Oily Press.

Intan SK, Tatang H, dan Dondy AS. 2012. Pengaruh kondisi homogenisasi terhadap karakteristik fisik dan mutu santan selama penyimpanan. J Littri.18(1): 31-39.

Harmayani E, Aprilia V, dan Marsono, Y. 2014. Characterization of glucomannan from Amorphophallus oncophyllusand its prebiotic activity in vivo. CabohydrPolym. 112: 475-479.

HaryaniKH, Raharjo BA, dan Dewi NWS. 2012. Pemanfaatan tepung glukomanan dari umbi porang (Amorphophallus oncophyllus) sebagai bahan baku pembuatan edible film. J Tek Kim Ind.1 (1): 401-411.

Ohtsuki T. 1968. Studies on reserve carbohydrates of flour Amorphophallus species, with special reference to mannan. Botanical Magazine Tokyo. 81: 119-126.

Jannah YR, Thohari I, dan Purwadi. 2013. The additionof porang flour (Amorphophallus oncophillus) in the yogurtice cream on total plate count, texture, taste, aroma, total solid and pH. [Skripsi]. Malang: Universitas Brawijaya.

Jiménez-Colmenero F, Cofrades S, Herrero A, Fernández-Martín F, Rodríguez-Salas L, Ruiz-Capillas C. 2012. Konjac gel fat analogue for use in meat products: comparison with pork fats. Food Hydrocol. 26(1): 63-72.

Koneva AS, Safonova EA, Kondrakhina PS, Vovk MA, Lezov AA, Chernyshev YuS, Smirnova NA. 2017. Effect of water content on structural and phase behavior of water-in-oil (n-decane) microemulsion system stabilized by mixednonionic surfactants span 80/tween 80. Colloids Surf A Physicochem Eng Asp. 518: 273-282.

Lee L dan Norton IT. 2013. Comparing droplet breakup for a high-pressure valve homogeniser and a microfluidizer for the potential production of food-grade nanoemulsions. J Food Eng. 114: 158-163.
Marie PJM, Perrier-Cornet, dan Gervais P. 2002. Influence of major parameters in emulsification mechanisms using a highpressure jet.JFood Eng. 53(1): 43-51.

McClements DJ. 2005. Food Emulsion: Principles, Practice, and Techniques. $2^{\text {nd }} \mathrm{ed}$. New York: CRS Press.

McClements J, Decker EA, dan Chaiyasit W. 2005. The Relationship Between the Physicochemical Properties of Antioxidants and Their Ability to Inhibit Lipid Oxidation in Bulk Oil and Oil-in-Water Emulsions. Departement of Food Science, University of Massachusetts Amherst.

Mulyono E, Risfaheri, Misgiyarta AW, Permana, Kurniawan F. 2009. Teknologi Produksi Tepung Mannan dari Umbi iles- iles (Amorphophallus Oncophillus) yang dapat Menghasilkan Rendemen $85 \%$ dan Derajat Putih $80 \%$. Makalah pada Seminar Hasil Penelitian SINTA TA. 2009, 9-10 Oktober 2009. Badan Penelitian dan Pengembangan Pertanian, Jakarta.

Pegg RB. 2005. Lipid Oxidation/Stability: Measurement of Primary Oxidation Product. Di dalam Wrolstad RE (ed.), Handbook of Food Analytical Chemistry: Water, Proteins, Lipids and Carbohydrates. New Jersey: Wiley Interscience. P515-529.

Sugandi E dan Sugianto. 1994. Rancangan Percobaan. Andi Offset, Yogyakarta.

Sumarwoto. 2007. Review: Kandungan mannan pada tanaman iles-iles (Amorphophallus muelleri Blume.). Bioteknol. 4 (1): 28-32.

Trujillo LS, Grau MAR, Forluny RS, Bellosa OM. 2013. Effect of processing parameters on physicochemical characteristics of microfluidized lemongrass essential oilalginate nanoemulsions. Food Hydrocol. 30: 401-407.

Vazquez-Ovando A, Betancur-Ancona D, ChelGuerrero L. 2013. Physicochemical and functional properties of a protein-rich fraction produced by dry fractionation of chia seeds (Salvia Hispanica L.).CyTA-J Food.1: 75-80.

Wang Y, Liu W, Chen XD, Selomulya C. 2016. Micro-encapsulation and stabilization of DHA containing fish oil in protein-based emulsion through mono-disperse droplet spray dryer. J Food Eng. 175: 74-84.

Weiss J. 2002. Unit D 3.4: Emulsion stability determination. Di dalam Decker, E (ed.),Current Protocols in Analytical Food Chemistry. New York: John Wiley \& Sons.

Wu YV. 2001. Emulsifying Activity and Emulsion Stability of Corn Gluten Meal. Fermentation Biochemistry Research Unit, National Center for Agricultural Utilization Research, Agricultural Research Service, 
U.S. Department of Agriculture, Peoria, IL 61604, USA.

Yanuriati I, Marseno DW, Rochmadi, Harmayani E. 2017. Characteristics of glucomannan isolated from fresh tuber of Porang (Amorphophallus muelleri Blume). Cabohydr Polym.156: 56-63.
ZhangYQ, Xie BJ, dan Gan K. 2005. Advance in the application of porang glucomannan and its derivatives. Cabohydr Polym.60: 27-31. 